\title{
Novelties from the Northern Mountains Complex of Madagascar V: A new threatened Pandanus (Pandanaceae) from the Kalobinono massif
}

\author{
Martin W. Callmander, Richard Razakamalala, Iacopo Luino, \\ Roger Lala Andriamarisoa \& Sven Buerki
}

\begin{abstract}
CALLMANDER, M.W., R. RAZAKAMALALA, I. LUINO, R.L. ANDRIAMARISOA \& S. BUERKI (2020). Novelties from the Northern Mountains Complex of Madagascar V: A new threatened Pandanus (Pandanaceae) from the Kalobinono massif. Candollea 75: 99-105. In English, English and French abstracts. DOI: http://dx.doi.org/10.15553/c2020v751a10

A new species of Pandanus Parkinson (Pandanaceae) endemic to Madagascar is described as Pandanus kalobinonensis Callm., Razakamal. \& Luino and illustrations are provided. The new species is restricted to the north-western lowland moist evergreen forests of the Kalobinono massif. Pandanus kalobinonensis can easily be morphologically distinguished from other members of the genus by its small solitary globose syncarp borne on a short peduncle, monocarpellate drupes, and single spiniform stigma with an adaxial stigmatic groove. Despite the occurrence of both collections within limits of the newly designated Galoko-Kalobonino Protected Area, the new species is preliminary assessed as "Endangered" [EN] using the IUCN Red List Criteria.
\end{abstract}

\section{Résumé}

CALLMANDER, M.W., R. RAZAKAMALALA, I. LUINO, R.L. ANDRIAMARISOA \& S. BUERKI (2020). Nouveautés du Complexe des Montagnes du Nord de Madagascar V: Un nouveau Pandanus (Pandanaceae) menacé du massif du Kalobinono. Candollea 75: 99-105. En anglais, résumés anglais et français. DOI: http://dx.doi.org/10.15553/c2020v751a10

Une nouvelle espèce de Pandanus Parkinson (Pandanaceae) endémique de Madagascar est décrite comme Pandanus kalobinonensis Callm., Razakamal. \& Luino et des illustrations sont fournies. La nouvelle espèce a une aire de distribution restreinte dans les forêts denses humides sempervirentes de basse altitude du massif du Kalobinono dans le nord-ouest de Madagascar. La nouvelle espèce se distingue facilement des autres membres du genre par son petit syncarpe globuleux solitaire, porté par un pédoncule court, ses drupes monocarpellées surmontées d'un stigmate spiniforme portant la zone stigmatique sur la face adaxiale. Malgré le fait que les deux récoltes se trouvent dans les limites de la nouvelle aire protégée du Galoko-Kalobonino, la nouvelle espèce est préalablement évaluée comme «En danger» [EN] en utilisant les critères de la Liste Rouge de l'UICN.

\section{Key-words}

PANDANACEAE - Pandanus - Madagascar - Galoko-Kalobinono - New species - IUCN Red List

\footnotetext{
Addresses of the authors:

MWC, IL: Conservatoire et Jardin botaniques de la Ville de Genève, ch. de l'Impératrice 1, C.P. 71,

1292 Chambésy, Switzerland. E-mail: martin.callmander@ville-ge.ch

RR, RLA: Missouri Botanical Garden, B.P. 3391, Antananarivo 101, Madagascar.

SB: Department of Biological Sciences, Boise State University, Boise, ID 83725, USA.

Submitted on March 16, 2020. Accepted on April 24, 2020.
}

First published online on May 12, 2020 


\section{Introduction}

The Galoko mountain range is located at the northern edge of the Sambirano Region (GACHET, 1958), which consists of the Isalo Sandstone (BESAIRIE, 1936) comprising two main summits: the Galoko (1,148 m) and the Kalobinono (1,028 m) (Fig. 1).This mountain chain has been botanically poorly studied since the 21th century. The botanical inventory of the Galoko-Kalobinono region began with Henri Perrier de la Bâthie (1873-1958) who visited the area twice between 1908 and 1923. Later, botanists from the "Service Forestier" conducted fieldwork in this region; however less than 50 collections were made during the 20th century. Starting in 2004, intensive botanical inventories have generated a total of 1412 collections for this region (CALLMANDER et al., 2018). This collection effort has revealed several new species in families such as Anacardiaceae (RANDrianasolo \& Lowry, 2009), Annonaceae (Callmander et al. 2009a; Johnson \& Murray, 2020), Araliaceae (Callmander et al., 2009a), Burseraceae (DAly et al.,2015), Malvaceae and Meliaceae (Callmander et al., 2009a), Oleaceae (Callmander et al. 2009a; Hong-Wa, 2016), Pandanaceae (CAllmander et al., 2008), Rubiaceae (De Block, 2014), Sapindaceae (Schatz et al., 2017) and Violaceae (WAHLERT, 2016). Overall, a total of 14 species are currently endemic to the Galoko-Kalobinono massifs (CAllmander et al., 2018).

These botanical discoveries have shed light on the unique biodiversity of the Galoko-Kalobinono region, which is facing high human pressure as demonstrated by a deforestation rate in the Galoko of 158,36 ha/year (RANirison et al., 2014). A multidisciplinary biodiversity inventory has been published by a consortium of Malagasy NGOs (the Missouri Botanical Garden-Madagascar, the Vahatra association, and the Bibikely Biodiversity Institute from the California Academy of Sciences). This biodiversity inventory was prepared in the context of the "Protected Areas of Managed Resources" (MRPA) program, which aimed at expanding the protected areas network of Madagascar within representative ecoregions, while considering regional population growth (see RANIRIson et al., 2014). Following this effort, a new protected area of 74,205 ha was designated for this region in 2015 (MEEF, 2015), the "Paysage Harmonieux Protégé de Galoko-Kalobinono". This protected area includes 11,739 ha of strict conservation ("noyau dur"). The Missouri Botanical Garden has been managing the protected area between 2013 to 2017 and the Famelona association has taken over management duties since 2018 [www.famelona.mg].

Pandanaceae of the Galoko-Kalobinono region have been well studied and currently comprises five species distributed into two genera. Martellidendron cruciatum (Pic. Serm.) Callm. \& Chassot, Pandanus boivinii Solms, P. grallatus B.C Stone, $P$. sambiranensis Martelli, and P. mammillaris Martelli \& Pic. Serm. have been recorded from the Protected Area. Those latter five species are not endemic to the region and occur in several neighboring forests (see Madagascar Catalogue, 2020).
Martellidendron cruciatum has a widespread distribution in Malagasy moist forests, whereas the other species are mostly endemic to the Sambirano Domain, a region well known for its high level of endemism (see Gautier, 2002). Currently, P. sermollianus Callm. \& Buerki is the only endemic species of the Galoko-Kalobinono region. This species was discovered in 2005 during the first intensive botanical inventory of this region (Callmander et al., 2008).

During the MRPA program, an unidentified collection of Pandanus Parkinson was collected at low elevation in the Kalobinono massif in 2013 by RR (Razakamalala et al. 7586). Another collection tentatively assigned to the same taxon was made by RR and IL in 2015 (Luino E Razakamalala 106) on the first author initiative. These two collections confirmed a further new species endemic to the Galoko-Kalobinono region, which is formally described and illustrated in this publication: Pandanus kalobinonensis Callm., Razakamal. \& Luino. The new species description is accompanied by notes on its morphological affinities, its preliminary risk of extinction assessment following IUCN Red List Categories and Criteria (IUCN, 2012), a field photograph and a line drawing.

\section{Taxonomy}

Pandanus kalobinonensis Callm., Razakamal. \& Luino, sp. nov. (Fig. 2,3).

Holotypus: Madagascar. Reg. DiANA [Prov. Antsiranana]: Fkt. Anketrabe-Belinta, massif du Kalobinono, 133' $42^{\prime}$ "S 48 40'29"E, 740 m, 16.X.2015, fr., Luino \& Razakamalala 106 (G [G00341880]!; iso-: TAN!).

Haec species ab omnibus congeneris syncarpio parvo globoso solitario brevipedunculato atque drupis monocarpellatis in stigma spiniforme adaxialiter sulcatum desinentibus differt.

Treelet to 3-4 $\mathrm{m}$ tall; stem prickly, up to $5 \mathrm{~cm}$ dbh. Leaves $125-160 \mathrm{~cm}$ long, $2-3 \mathrm{~cm}$ wide in the middle, $3 \mathrm{~cm}$ wide near the sheath, gradually attenuate in the upper third, and tapering to a flagellate apex in the distal $5 \mathrm{~cm}$, coriaceous; longitudinal and transverse veins visible on both surfaces; prickles white in vivo; marginal prickles beginning at (4-)5-6 $\mathrm{cm}$ above the base and extending to the apex, antrorse, $2-4 \mathrm{~mm}$ and placed 2-8 $\mathrm{mm}$ apart in the lower third, to $2 \mathrm{~mm}$ and $5-10 \mathrm{~mm}$ apart in the middle third; to $<1 \mathrm{~mm}$ and $2-4 \mathrm{~mm}$ apart in the distal third; midrib armed below in the upper $2 / 3$, prickles small $(<1 \mathrm{~mm})$, irregularly disposed $(5-10 \mathrm{~mm})$; sheath $5 \mathrm{~cm}$ long, c. $3.5 \mathrm{~cm}$ wide at apex c. $4-4.5 \mathrm{~cm}$ large at base. Infrutescence terminal, a solitary syncarp subtended by naviculate bracts, borne on a straight short peduncle; syncarp $50 \times 60-70 \mathrm{~mm}$, globose to ovoïd; peduncle straight, short, $65 \mathrm{~mm}$ long, c. $9 \mathrm{~mm}$ in diam at apex, trigonous, $3-4$ remaining bracts, c. 5-7.5 cm long, positioned near the base of the syncarp, boat-shaped at base and becoming flagellate in the distal part. 


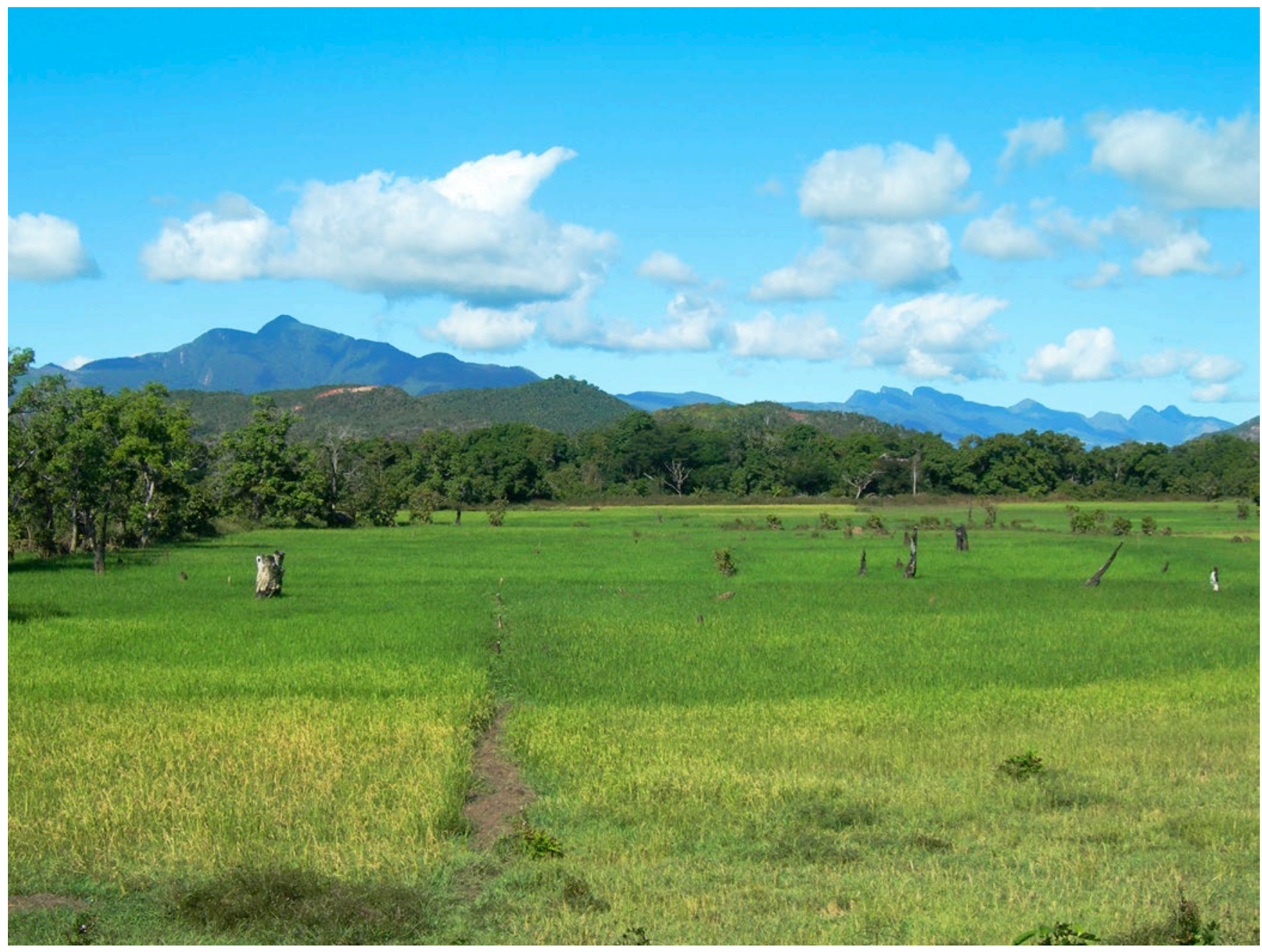

Fig. 1. - The Galoko mountain range with the Galoko summit on the left, the distinctly shaped domes of the Kalobinono on the right and rice plantations in the foothills. [Photo: S. Wohlhauser]

Drupes c. 65-140 per syncarp, (15-)20(-25) mm high, 5-7 mm wide, (3-)4-6 mm thick, 4-6 angled; carpel 1, free in the upper fourth, tapering to the base; pileus pyramidal, somewhat rounded at apex. Stigma 1, erect or curved, spiniform, on the centre of the apical face of the pileus, brown in vivo, 3-5 $\mathrm{mm}$ in length, stigmatic groove abaxial, covering c. $2 / 3$ of the length of the stigma. Endocarp 10-13 $\mathrm{mm}$ long in the centre, $<1 \mathrm{~mm}$ wide, 4-6 $\mathrm{mm}$ away from stigma base; seed locule oblong, $10-12 \times 3-5 \mathrm{~mm}$, superior and inferior mesocarp fibrous. Staminate plant unknown.

Etymology. - The species epithet refers to the Kalobinono massif and its eroded landscape of Isalo Sandstone dominated by a pair of distinctly shaped domes (fig. 1). The literal translation from the Sakalava dialect means "princess with large breasts". Similarly, the name Galoko refers to a local king. The two summits are sacred for the local Sakalava. According to the legend, the queen embodied in the Kalobinono massif gave birth to the nearby Manongarivo massif, fathered by the king at Galoko (Solo et al., 2008).

Distribution and ecology. - Pandanus kalobinonensis is currently only known from the lowland moist evergreen forest in the Kalobinono massif (northwestern Madagascar) between 420 to 740 m elevation.

Conservation status. - Pandanus kalobinonensis is known from 2 locations from the Galoko-Kalobinono Protected Area collected at a distance of c. $1 \mathrm{~km}$ in lowland moist evergreen forests. The holotype collection is located well within the intact forest at $740 \mathrm{~m}$, but the paratype is located at $425 \mathrm{~m}$ and was made only a hundred meters from recently cleared forest. This latter location could be projected to disappear in a relatively near future. Lowland moist evergreen forests were highly threatened in the 


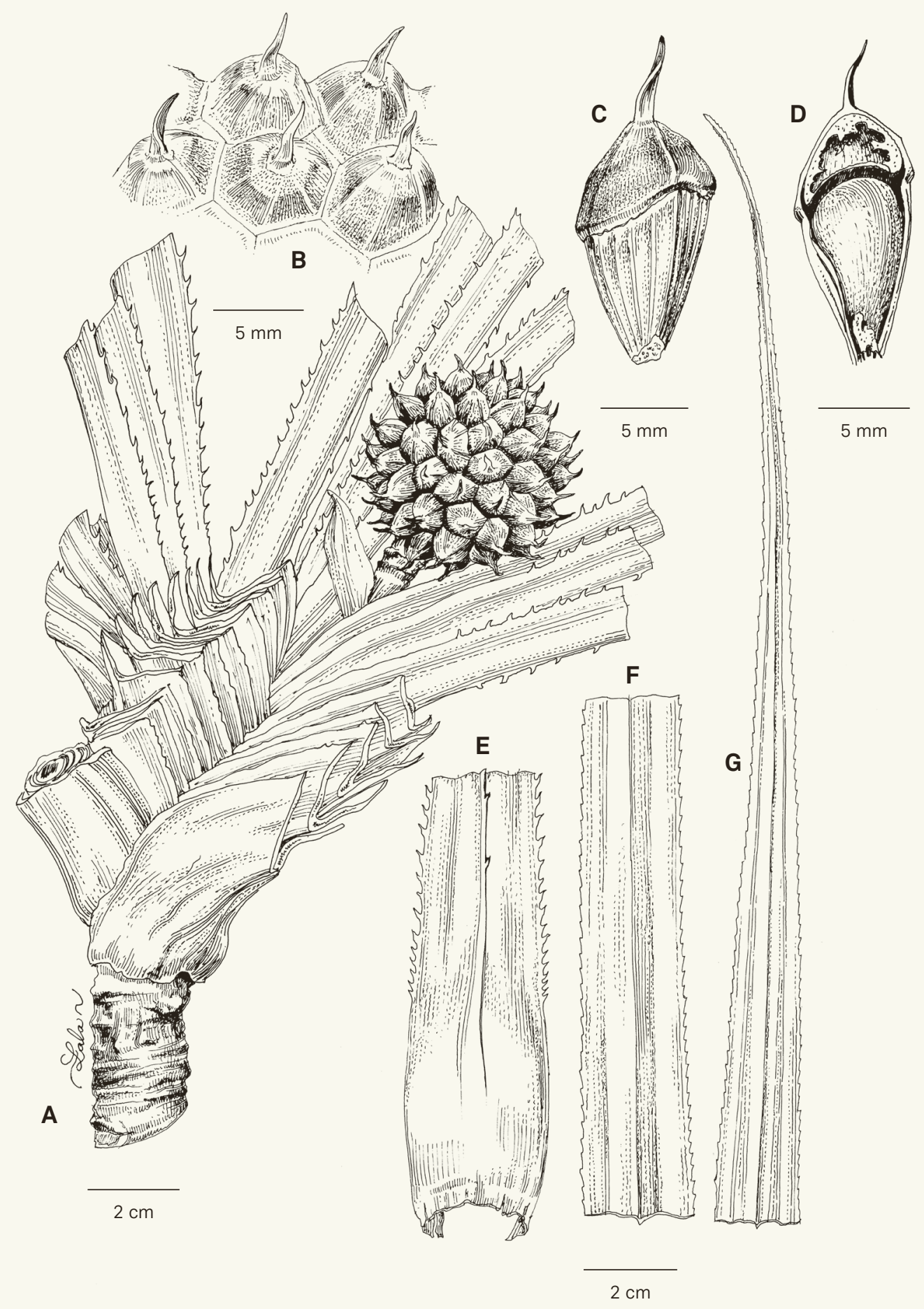

Fig. 2. - Pandanus kalobinonensis Callm., Razakamal. \& Luino. A. Fruiting branch; B. Detail of the syncarp; C. Drupe; D. Cross section of a drupe; E. Basal section of a leaf; F. Mid section of a leaf; $G$. Apex section of a leaf.

[A-D: Razakamalala et al. 7586, TAN; E-G: Luino \& Razakamalala 106, TAN] [Drawing: R.L. Andriamiarisoa] 


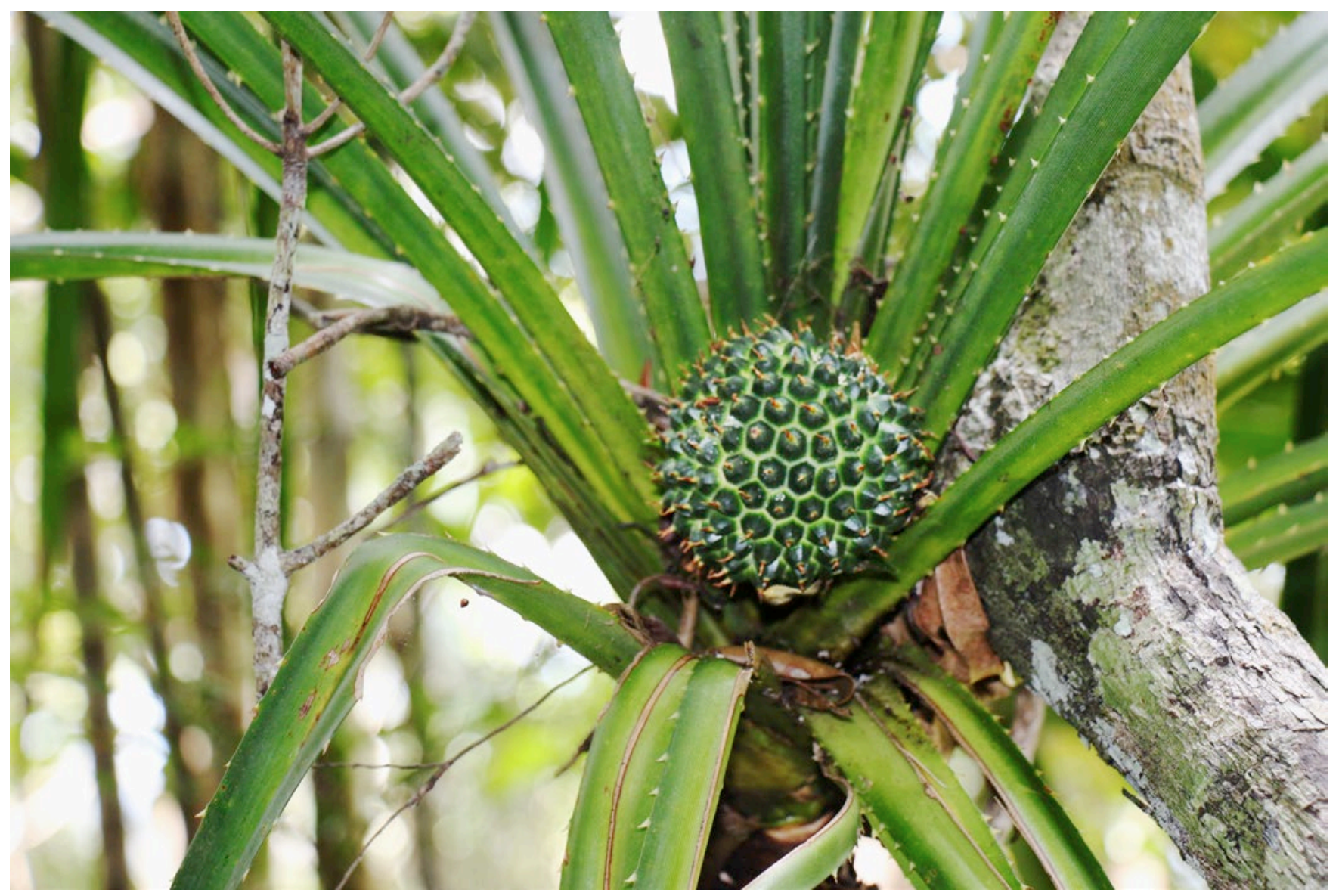

Fig. 3. - Photograph of Pandanus kalobinonensis Callm., Razakamal. \& Luino. [Luino \& Razakamalala et al. 106] [Photo: I. Luino]

massifs where Tsimihety immigrants have established settlements for several decades and are practicing slash and burn agriculture (Solo et al., 2008) (Fig. 1). The loss of moist evergreen forest area between 2006 to 2016 has reached 1408 ha, which represents $15 \%$ of the total cover of the PA (RABENANDRASANA et al., 2018). Since mid 2018, slash and burn agriculture is restricted within the strict conservation zone, but the risk of uncontrolled pasture fire is still a threat (P. Ranirison, pers. comm.). With an area of occupancy (AOO) of $4 \mathrm{~km}^{2}$, and despite that both collections ocur within limits of the protected area, P. kalobinonensis is therefore assigned a preliminary conservation status of "Endangered" [EN B1ab(ii,iii,iv,v)+2ab(ii,iii,iv,v)] using IUCN Red List Categories and Criteria (IUCN, 2012).

Notes. - Pandanus kalobinonensis is morphologically distinct among Malagasy species of Pandanus. Its small globose solitary syncarp bearing monocarpellate drupes topped by a spiniform stigma (Fig. 2,3) resembles several Southeast Asian Pandanus species. Several species in Madagascar were hypothesized to have morphological Indo-Malaysian affinities (STONE 1974; Callmander \& Laivao, 2003). Pandanus platyphyllus Martelli was for example placed by STone (1974) in the Malaysian Pandanus subgenus Rykia (Vrise) B.C. Stone before staminate plants were studied by Huynh (1977) and confirmed to belong to the Afro-Malagasy subgenus Vinsonia (Warb.) B.C. Stone. Phylogenetic analyses further demonstrated that those latter morphological affinities were most likely the result of convergent evolution since all Malagasy species of Pandanus subgenus Vinsonia formed a monophyletic clade (BuERKI et al., 2012). In this context, Pandanus kalobinonensis is therefore classified in Pandanus subgenus Vinsonia. The sectional placement of this species remains to be established, like other recently discovered morphologically isolated species in Madagascar (see Callmander et al., 2008, 2009b, 2013).

Paratypus. - Madagascar. Reg. DIANA [Prov. Antsiranana]: Beramanja, Anketrabe Belinta, massif du Kalobinono, 13³8'16"S 48 40'21"E, 425 m, 29.IX.2013, fr., Razakamalala et al. 7586 (TAN). 


\section{Acknowledgements}

We are especially grateful to Sylvie Andriambololonera for her crucial support, Roy Gereau for preparing the Latin diagnoses, Patrick Ranirison for providing reports and information on the Galoko-Kalobinono Protected Area, George Schatz for advice on the conservation status assessment and Sébastien Wohlhauser for his photograph of the mountain chain and his tireless enthusiasm and support in the discovery and protection of the Galoko and Kalobinono massifs. Finally, we are thankful to Laurent Gautier and Patrick Ranirison for their careful reviews, which greatly improved our manuscript and Lorenzo Ramella for his proofreading.

\section{Bibliography}

Besairie, H. (1936). Recherches géologiques à Madagascar, première suite; la géologie du nord-ouest. Mém. Acad. Malgache 21: 1-259.

Buerki, S., M.W. Callmander, D.S. Devey, L. Chappell, T. Gallaher, J. Munzinger, T. Haevermans \& F. Forest (2012). Straightening out the screw-pines: a first step in understanding phylogenetic relationships within Pandanaceae. Taxon 61: 1010-1020.

Callmander, M.W. \& M.O. Laivao (2003). Biogeography and systematics of the Madagascan Pandanus (Pandanacaeae). In: Goodman, S.M. \& J.P. Benstead (ed.), The Natural History of Madagascar: 460-467. The University of Chicago Press, Chicago.

Callmander, M.W., S. Buerki \& S. Wohlhauser (2008). A new threatened species of Pandanaceae from northwestern Madagascar, Pandanus sermolliana. Novon 18: 421-424. DOI: https://doi. org/10.3417/2007101

Callmander, M.W., C. Rakotovao, J. Razafitsalama, P.B. Phillipson, S. Buerki, C. Hong-Wa, N. Rakotoarivelo, S. Andriambololonera, M.M. Koopman, D.M. Johnson, T. Deroin, A. Ravoahangy, S. Solo, J.-N. Labat \& P.P. Lowry II (2009a). New species from the Galoka and Kalabenono massifs: two unknown and severely threatened mountainous areas in NW Madagascar. Candollea 64: 179-202.

Callmander, M.W., L. Gautier \& S.M. Trigui (2009b). Pandanus nusbaumeri Callm. and L. Gaut. (Pandanaceae), a new endemic species from the Montagne d'Ambre (northern Madagascar). Candollea 64: 213-218.

Callmander, M.W., R. Bolliger, R.M. Hanitrarivo \& L. Nusbaumer (2013). Pandanus tsingycola Callm. and Nusb. (Pandanaceae), a new species endemic to western Madagascar. Candollea 68: 229-235. DOI: https://doi.org/10.15553/ c2012v682a6

Callmander, M.W., P.B. Phillipson, L.D. Andriamahefarivo \& P.P. Lowry II (2018). Flora. Site 10. Galoko-Kalobinono. In: Goodman, S.M., M.J. Raherilalao \& S. Wohlhauser (ed.),
The terrestrial protected areas of Madagascar: Their history, description, and biota: 589-593. Association Vahatra, Antananarivo.

Daly, D.C., J. Raharimampionona \& S. Federman (2015). A revision of Canarium L. (Burseraceae) in Madagascar. Adansonia ser. 3, 37: 277-345. DOI: http://dx.doi.org/10.5252/a2015n2a2

De Block, P. (2014). Eight new species of Ixora (Ixoreae - Rubiaceae) from Madagascar. Pl. Ecol. Evol. 147: 237-255.

Gachet, C. (1958). Les forêts du Sambirano et de Nossi-Bé. II. Les Presqu'îles d'Anorotsanga et d'Ambato, le Kalobenono, le Galoko, Nosy Be et Nosy Komba. Bull. Madagascar 151: 1043-1064.

Gautier, L. (2002). Liste commentée des phanérogames de la Réserve Spéciale de Manongarivo, Madagascar. In: Goodman, S.M. \& L. Gautier (ed.), Inventaire floristique et faunistique de la Réserve Spéciale de Manongarivo (NW Madagascar). Boissiera 59: 105-239.

Hong-WA, C. (2016). A taxonomic revision of the genus Noronhia Stadtm. ex Thouars (Oleaceae) in Madagascar and the Comoro Islands. Boissiera 70.

Huynh, K.-L. (1977). L'appareil mâle de quelques Pandanus du sousgenre Vinsonia (Pandanaceae) et sa signification taxonomique, phylogénique et évolutive. Beitr. Biol. Pfanzen. 53: 447-471.

IUCN (2012). IUCN Red List Categories and Criteria: Version 3.1. Ed.2. IUCN Species Survival Commission, IUCN, Gland \& Cambridge.

Johnson, D.M. \& N.A. Murray (2020). Révision du genre Xylopia L. (Annonaceae) : les espèces de Madagascar et des îles Mascareignes. Adansonia ser. 3, 42: 1-88. DOI: https://doi.org/10.5252/ adansonia2020v42a1

Madagascar Catalogue (2020). Catalogue of the Plants of Madagascar. Missouri Botanical Garden, St. Louis \& Antananarivo. [http://www.tropicos.org/Project/Madagascar]

MEEF [Ministère de L'Environnement, de L'Écologie et DEs ForÊTs] (2015). Décret no 2015-770 portant création d'Aire Protégée dénommée "Galoko-Kalobinono» communes rurales de Beramanja, Aanaborano Ifasy, Maherivaratra, Antsakoamanondro, Ambodimanga Ramena, district Ambilobe et Ambanja Région Diana. Antananarivo.

Rabenandrasana, J.C.N., S. Wohlhauser \& S.M Goodman (2018). Forest Loss. Site 10. Galoko-Kalobinono. In: Goodman, S.M., M.J. Raherilalao \& S. Wohlhauser (ed.), The terrestrial protected areas of Madagascar: Their history, description, and biota: 595. Association Vahatra, Antananarivo.

Randrianasolo A. \& P. P. Lowry II (2009). Four new species and one new combination in the Malagasy endemic genus Micronychia Oliv. (Anacardiaceae). Adansonia ser. 3,31: 157-168. DOI: https://doi.org/10.5252/a2009n1a10

Ranirison, P., F. Ratovoson, A. Tahinarivony, N. Manjato, M. Randriantsivery, B. Rakotozafy, C. Claude, N. Rasoanaivo, R. Razakamalala, M.J. Raherilalao, M. Randrianarisoa, V. Soarimalala, J. Ralison, C. Raharisoa, J. Ralambomanana, 
L. Randriamanana, T. Radovimiandrinifarany, J.J. Rafanomezantsoa, J.-C. Rakotonirina, A. Razanakoto, L. Rasoalinoro, N. Ratovoson \& Z. Rabemananjara (2014). Inventaires de références des sites du projet MRPA - Lot no1 Ampasindava-Galoka - DP No 01-13 /DP/UCPE/MRPARapport final. Missouri Botanical Garden, Association Vahatra et Bibikely Biodiversity Institute (CAS), Antananarivo.

Schatz, G.E., R.E. Gerau \& P.P. Lowry II (2017). A revision of the endemic Malagasy genus Beguea (Sapindaceae). Candollea 72: 45-65. DOI: https://doi.org/10.15553/c2017v721a6

Solo, S., C. Rakotovao, M.W. Callmander \& R. Andriamandranto (2008). Plan stratégique de conservation de la forêt du complexe Kalabenono. Missouri Botanical Garden, Antananarivo.

Stone, B.C. (1974). Towards an improved infrageneric classification in Pandanus (Pandanaceae). Bot. Jahrb. Syst. 94: 459-540.

Wahlert, G.A. (2016). Novelties from the Northern Mountains Complex of Madagascar IV: A new Rinorea Aubl. (Violaceae) of restricted range from the Galoko and Kalabinono massifs. Candollea 71: 205-210. DOI: https://doi.org/10.15553/ c2016v712a6 